\title{
EMPLOYMENT OPPORTUNITY: CLASS MEMBERSHIP FOR TITLE VII ACTION NOT RESTRICTED TO PARTIES PRE- VIOUSLY FILING CHARGES WITH THE EEOC
}

In Oatis v. Crown Zellerbach Corp.' the Fifth Circuit, permitting a class action for injunctive relief under Title VII of the Civil Rights Act of $1964,{ }^{2}$ held that although the employment discrimination issues which are triable in the civil action must be limited to those previously raised in a charge filed with the Equal Employment Opportunity Commission (EEOC), class membership is not restricted solely to parties who have themselves filed charges with the EEOC, but rather is extended to include nonfiling parties who assert the same or some of the same allegations of discrimination as were made in a prior EEOCfiled charge. Four Negro employees of Crown's Bogalusa, Louisiana, plant filed suit on behalf of themselves and all present and prospective Negro employees of the plant, as a class, seeking injunctive relief against unfair employment practices allegedly committed by the company and two local unions in violation of Title VII. ${ }^{3}$ Since, prior to suit, only one of the plaintiffs had filed formal charges with the EEOC in the manner provided for under section 706(a) of the Act, ${ }^{4}$ the defendants moved to dismiss on the grounds that permitting a class action to be based on the single filed charge would circumvent the administrative procedure set up by the Act and result in the court's displacing the role of the EEOC. Apparently persuaded by this reasoning, the district court ruled that although a class action could be maintained, the class would be limited to those employees who had themselves filed charges with the EEOC. ${ }^{5}$ Reversing the district court's dismissal of the nonfiling plaintiffs' actions, the court of appeals held that nonfiling class members are proper parties to a class

\footnotetext{
1398 F.2d 496 (5th Cir. 1968).

242 U.S.C. $\$ 2000 \mathrm{e}(1964)$.

${ }^{3}$ See id. at $\$ \S 2000 \mathrm{e}-2 \&-3$ (enumerating enjoinable unfair employment practices).

4 Id. at $\$ 2000 \mathrm{e}-5$ (a).

${ }^{5}$ Mondy v. Crown Zellerbach Corp., 271 F. Supp. 258, 264 (E.D. La. 1967).
} 
action for injunctive relief under Title VII provided that the action otherwise meets the requirements of Rule 23 of the Federal Rules of Civil Procedure. ${ }^{6}$

Although the EEOC is empowered to attempt the elimination of unlawful employment practices by informal methods of conference, conciliation, and persuasion, ${ }^{7}$ actual enforcement of Title VII proscriptions rests exclusively with the federal courts. Nevertheless, the vast majority of courts have held that the filing with the EEOC of a written charge of discrimination is a prerequisite to the seeking of judicial relief, ${ }^{8}$ and the Act itself provides that an aggrieved party may file such a charge no later than ninety days after the alleged discriminatory act." The "permissive rather than prohibitive"10 tenor of the Act's language, however, casts considerable doubt on the necessity of prior filing with the EEOC. ${ }^{11}$ The statute itself does not explicitly state that an individual may not sue unless he has filed with the EEOC-a procedural prerequisite which could have been expressly provided for by Congress. Furthermore, the Act's admittedly "chaotic legislative history" 12 tends to indicate that the EEOC was not to "hold the key to the courtroom door,"13 but rather was intended to provide an administrative alternative to immediate judicial recourse. Such an interpretation of the Title VII enforcement scheme may be partially responsible for the conflict which has

${ }^{6}$ See FED. R. CIV. P. 23(a) \& (b).

${ }^{7} 42$ U.S.C. § 2000e-S(a) (1964).

'See, e.g., Stebbins v. Nationwide Mutual Ins. Co., 382 F.2d 267 (4th Cir. 1967), cert. denied, 390 U.S. 910 (1968) (plaintiff cannot bypass EEOC and apply directly to courts for relief); Mickel v. South Carolina State Employment Service, 377 F.2d 239, 242 (4th (ir.), cert. denied, 389 U.S. 877 (1967) (plaintiff must satisfy statutory requirements prior to institution of civil action); Mondy v. Crown Zellerbach Corp., 271 F. Supp. 258 (E.D. La. 1967) (aggrieved party may bring suit only after filing charge with EEOC). Contra, Hall v. Werthan Bag Corp., 251 F. Supp. 184 (M.D. Tenn. 1966) (filing of a complaint with the EEOC not a condition precedent to right to file aetion in court).

942 U.S.C. § 2000e-5(d).

${ }^{10}$ Walker, Title VII: Complaint and Enforcement Procedures and Relief and Remedies, 7 B.C. Indus. \& Comm. L. Rev. 495, 497 (1966).

"Id. at 497-98. It may be argued that an individual can bypass the EEOC and sue directly under section 703 of the Act, which prohibits employment discrimination, and that the enforcement scheme established by section 706 , involving conciliatory activities by the Commission, applies only when the individual elects to use the offices of the EEOC to assist him in handling his claim.

${ }^{12}$ Hall v. Werthan Bag Córp., 251 F. Supp. 184, 186 (M.D. Tenn. 1966).

${ }^{13} 110$ CoNG. Rec. 14191 (1964) (remarks of Senator Javits concerning conciliation and filing). See also 110 CoNG. Rec. 14188 (1964) (Senator Humphrey); Walker, supra note 10. 
developed over whether actual conciliation efforts by the Commission are also a condition precedent to the bringing of civil suit. ${ }^{14}$ The statutory language is again unclear, providing that if the EEOC is unable to obtain voluntary compliance within sixty days after a charge is filed, it shall so notify the complaining party, who may then institute a civil action within thirty days thereafter. ${ }^{15}$ Adhering to the rationale that "Congress intended .. . persons claiming discrimination in employment [to] first exhaust their remedies within the Commission created for that purpose,"16 several courts have agreed that actual conciliation must have been attempted by the EEOC before a civil action may be brought. ${ }^{17}$ Recognizing that the short sixty-day conciliation period is frequently insufficient to allow for actual conciliation attempts, the courts requiring actual conciliation measures have held that the sixty-day period is to be accorded a "directory rather than mandatory construction," 18 with the result that notification delays of several months by the EEOC have been tolerated. ${ }^{19}$ Other courts though not requiring actual conciliation attempts, have insisted on strict compliance with the sixtyday limitation..$^{20}$ In these cases plaintiffs were denied relief because. their civil actions were not instituted within ninety days after the filing of their original EEOC charges. Thus, the courts generally required strict adherence to the initial sixty-day period with the thirty-day time limitation on bringing civil suit commencing immediately thereafter. Apparently, however, the trend is away from both the mandatory interpretation of the sixty-day period and the conciliation

${ }^{4}$ See, e.g., Dent v. St. Louis-San Francisco Ry., 265 F. Supp. 56 (N.D. Ala. 1967) (conciliation a jurisdictional prerequisite to civil action under Title VII); accord, Mickel v. South Carolina State Employment Service, 377 F.2d 239 (4th Cir. ), cert. denied, 389 U.S. 877 (1967). Contra, Quarles v. Philip Morris, Inc., 271 F. Supp. 842 (E.D. Va. 1967); Moody v. Albemarle Paper Co., 271 F. Supp. 27 (E.D.N.C. 1967); Evenson v. Northwest Air Lines, 268 F. Supp. 29 (E.D. Va. 1967) (conciliation attempts by EEOC not prerequisite to suit under Title VII).

1542 U.S.C. $\$ 2000 \mathrm{e}-5$ (e) (1964).

${ }^{16}$ Mickel v. South Carolina State Employment Service, 377 F.2d 239, 242 (4th Cir.), cert. denied, 389 U.S. 877 (1967).

"See, e.g., id. Dent v. St. Louis-San Francisco Ry., 265 F. Supp. 56 (N.D. Ala. 1967).

14265 F. Supp. at 58.

19 265 F. Supp. 56 (N.D. Ala. 1967); see e.g., Evenson v. Northwest Air Lines, 268 F. Supp. 29 (E.D. Va. 1967) (delay of 71 days before EEOC notified plaintiff).

${ }^{20}$ See, e.g., Miller v. International Paper Co., 56 CCH LAB. CAS. II 9093 (S.D. Miss. 1967); Cunningham v. Litton Industries, 56 CCH LAB. CAS. I 9078 (C.D. Cal. 1967). But sce note 21 infra (cases requiring neither conciliation attempts nor compliance with sixty-day limitation). 
requirement. ${ }^{21}$ A compelling argument behind the change in attitude recently expressed by one court was that to bar a suit because of the EEOC's failure to attempt conciliation is to unfairly penalize a plaintiff for circumstances totally beyond his control. ${ }^{22}$ In addition, the Third Circuit has recently held that Title VII imposes no time limit on the EEOC for serving or processing the discrimination complaint, ${ }^{23}$ thereby indicating that the thirty-day period for bringing civil action commences upon receipt of notification from the EEOC that it has been unable to conciliate. Such Jiberalization of the Title Vll enforcement scheme seems destined to lessen the hardships imposed by the interaction of the filing requirement with the short statutory time limits, thus making judicial relief more accessible. Once in court, the complainant may. seek to have the discriminatory practices enjoined; and the court may "order appropriate . . . [affirmative relief such as] . . . reinstatement or hiring of employees, with or without back pay . . . .".24

The class action is uniquely adapted to Title VlI enforcement, not only because discrimination is necessarily class-directed, but also because such actions permit a privately instituted suit to further the public interest of eliminating discriminatory employment practices. Thus, in Oatis a single complaint filed with the EEOC was sufficient to enable the court to disseminate class-wide injunctive relief in a single suit. However, the courts thus far have refused to grant affirmative relief on such a basis, limiting the availability of monetary redress to those parties who have filed with the EEOC. ${ }^{25}$ Consequently, although recently-amended Rule $23^{26}$ was thought to have eliminated the spurious class action with its limited res judicata

\footnotetext{
"See, e.g., Mondy v. Crown Zellerbach Corp., 271 F. Supp. 258 (E.D.La. 1967); Evenson v. Northwest Air Lines, 268 F. Supp. 29 (E.D. Va. 1967).

${ }^{22}$ See, e.g., Evenson v. Northwest Air Lines, 268 F. Supp. 29 (E.D. Va. 1967).

${ }^{23}$ Electrical Workers, Local No. 5 v. EEOC, _ F.2d__ (3d Cir. 1968).

2442 U.S.C. $\$ 2000 \mathrm{e}-5(\mathrm{~g})(1964)$.

${ }^{25}$ See, e.g., Hall v. Werthan Bag Corp., 251 F. Supp. 184 (M.D. Tenn. 1966). See generally Griggs v. Duke Power Co., 56 CCH Lab. Cas. ๆ 9091 (M.D.N.C. 1967); Anthony v. Brooks, 55 CCH Lab. Cas. I 9064 (N.D. Ga. 1967); Bowe v. Colgate-Palmolive Co., 272 F. Supp. 332 (S.D. Ind. 1967); Quarles v. Philip Morris, Inc., 271 F. Supp. 842 (E.D. Va. 1966); Gardner, The Procedural Steps of Title VII of the Civil Rights Act of 1964, 29 ALA. LAw. 80 (1968); Morse, The Scope of Judicial Relief Under Title VII of the Civil Rights Act of 1964, 46 TEXAS L. REv. 516 (1968).

${ }^{26}$ Compare FeD. R. Civ. P. 23 with Fed. R. Civ. P. 23, at 39 F.R.D. 96 (1966).
} 
effect, ${ }^{27}$ a "class action" for specific affirmative redress under Title V1l constitutes little more than the permissive joinder of prior-filing plaintiffs and so assumes a stature reminiscent of the "defunct" spurious class action. However, in contrast to the effect of judgment upon non-intervening parties in the spurious class action, a nonfiling Title VII plaintiff will be bound by the res judicata effect of judgment in an action for affirmative redress if the action additionally seeks injunctive relief. ${ }^{28}$ According to Rule $23^{29}$ and court decisions, ${ }^{30}$ the judgment granting or denying the injunction will be binding on all nonfiling class members provided there is a "sufficient showing of fair play [and representation] to satisfy the requircment of due process." 31 Thus, the limited availability of affirmative class action relief under Title V1I is especially harsh when the res judicata effect of the class action judgment is considered with respect to the Act's filing requirement and unusually short "statute of limitations." A nonfiling party who is unable to seek monetary redress because of expiration of the ninety-day period for filing with the Commission ${ }^{32}$ may be hindered in his attempt to retain competent legal counsel who will adequately present his case. Yet, such a nonfiling party, because he is a class member for purposes of injunctive relief, will be bound by the collateral estoppel effect of the judgment. ${ }^{33}$ This inequitable result could be avoided by establishing a more liberal filing procedure under

\footnotetext{
${ }^{27}$ See Advisory Committee's Note, 39 F.R.D. 98 (1966). See generally 2 W. BARRoN \& A. Holtzoff, Federal Practice and Procedure $\S 572$ (1961) [hereinafter cited as Barron \& HoLTZOFF].

23 BARRON \& HoLTZOFF § 572. Under the "old" tripartite distinction of class actions, the spurious class action was unique in that only those parties who actually intervened in the class suit would be bound by the judgment. See generally Knowles v. War Damage Corp., 171 F.2d 15 (D.C. Cir. 1948), cert. denied, 336 U.S. 914 (1949); Comment, The Spurious Class Suit: Procedural and Practical Problems Confronting Court and Counsel, 53 Nw. U.L. REv. 627 (1958).

${ }^{29}$ FED. R. Civ. P. 23(c) (3),

${ }^{30}$ See, e.g., Hansberry v. Lee, 311 U.S. 32 (1940). See generally Note, 67 HARV. L. REV. 1059 (1954).

${ }^{31}$ BARRON \& HOLTZOFF $\S 572$, at 352.

${ }^{32}$ See 42 U.S.C. $\S 2000 \mathrm{e}-5$ (d) (1964). See also note 8 supra and accompanying text.

${ }^{33}$ See BARRON \& HoltzofF § 572, at 348-52. Under some circumstances collateral estoppel will result in disadvantaging, rather than helping, persons to whom Oatis class membership has been extended. For example, when the original class action seeks to enjoin the use of an allegedly discriminatory pre-employment written examination, a judicial determination that the test is not discriminatory would seem to preelude a nonfiling Oatis class member from later seeking to relitigate the factual issue regarding the test's discriminatory character. This would be the case despite the fact that the second action challenges the test's usage at a point in time subsequent to
} 
which a nonfiling class member would not be bound by the ninety-day filing period, ${ }^{34}$ and could thus qualify for affirmative relief in the privately instituted class action. Such a possibility is suggested by the statute of limitations treatment in purely judicial class actions, where it is well-settled that the commencement of the action by a single party halts the running of the statute of limitations for all members of the class. $^{35}$ Thus, if a single class member's filing with the EEOC had the effect of tolling the original ninety-day filing period, class members who had not filed with the Commission would be able to do so upon court notification $^{36}$ and thereby become eligible for affirmative relief. Such a posture does not seem an illegitimate liberalization of statutory language since the time periods enumerated by the Act were not addressed directly to the class action situation. Furthermore, the very nature of prerequisite filing appears particularly well-suited to such a result. As noted in Miller v. International Paper Co., insofar as filing is a qualifying step in the enforcement process which makes later suit possible, the filing period may be thought of as a statute of creation rather than limitation. ${ }^{37}$ This view is in contrast to the usual statute of limitations application in which an existent cause of action is extinguished by the expiration of a specified time period. Consequently, having created a cause of action, a single complaint timely filed should keep the door to redress open for other class members. To argue that such a liberal procedure circumvents the purposes for which the EEOC was created would seem to place perfunctory technicalities ahead of effective antidiscrimination

trial of the original action. Arguably, under FED. R. CIv. P. 23(c) (3) a class member might be able to avoid the collateral estoppel effect of judgment in the original action if he had requested exclusion from the class. See Advisory Committee's Note, 39 F.R.D. 98, 105-06 (1966). However, even if a class member is notified of the possibility of exclusion, it would require a certain degree of legal sophistication to appreciate the potential value of so excluding himself. As a practical matter, if the class action succeeds, a class member who excluded himself will nevertheless fully benefit from the court's granting of general injunctive relief. If the class action fails, a class member's previous exclusion may insulate him from the collateral estoppel effeet of the adverse judgment. Thus, a nonfiling party who is made a class member only for injunctive relief and who does not exclude himself, see Hall v. Werthan Bag Corp., 251 F. Supp. 184 (M.D. Tenn. 1966), would seem to suffer the worst of two worlds, being collaterally estopped by an adverse judgment but not entitled to affirmative relief under a favorable one.

34 42 U.S.C. $\S 2000 \mathrm{e}-5$ (d) (1964); supra note 8.

${ }^{35}$ See, e.g., Union Carbide \& Carbon Corp. v. Nisley, 300 F.2d 561 (10th Cir. 1961), cert. denied, 371 U.S. 801 (1963). See generally 3A J. Moore, Federal Practice iी 1 23.10, 23.12 (2d ed. 1963).

${ }^{36}$ FED. R. Crv. P. 23(c) (2) (provisions for notice).

" 56 CCH LaB. CAS. 10093 (S.D. Miss. 1967). 
enforcement. Indeed, if the discriminator is alerted to the fact that a single EEOC-filed charge may later serve as a basis for a class action seeking monetary redress, there should be a greater possibility that he will choose to conciliate.

In order for affirmative relief to be an effective Title VII enforcement incentive, however, it must be substantial enough to make civil action worthwhile. ${ }^{38}$ When the delay inherent in the typical Title VII suit is considered, ${ }^{39}$ it becomes apparent that "back pay minus interim wages" 40 is not always a sufficient inducement to undertake litigation, even if reasonable attorney's fees and costs are allowed. ${ }^{41} \mathrm{~A}$ partial solution to this general problem of inadequate remedial measures is the utilization of traditional tort remedies. ${ }^{42}$ Thus, damages for the intentional infliction of mental distress, a seemingly obvious result of racial discrimination, could provide a suitable basis for substantial monetary award, with additional "punitive" damages a distinct possibility. The application of such tort remedies to Title VII suits is immediately practicable under present statutory language. ${ }^{43}$

An alternative approach to the problcms inherent in prerequisite filing is to permit an aggrieved party to bypass the EEOC altogether: a suggestion not without legislative and judicial support. ${ }^{44}$ Pragmatically, the value of prerequisite filing is questionable in view of the poor record of successful conciliations effected by the overburdened and understaffed EEOC over the past two years..$^{45}$ Furthermore, in order to use the privately instituted suit as an effective enforcement vehicle, Title VII must make redress accessible to those individuals who suffer employment discrimination and must not present a morass of procedural technicalities. To attain notable results with such a poorly-informed and legally-naive segment of society, the most productive approach may be to permit individuals to "stumble" into the Title VII class suit at the judicial level where they

\footnotetext{
"See 54 VA. L. REv. 491 (1968).

${ }^{39}$ See 29 Orio ST. L.J. 456 (1968). Bureaucratic delays of several months are not uncommon. See note 19 supra.

${ }^{40} 42$ U.S.C. $\$ 2000 \mathrm{e}-5(\mathrm{~g})(1964)$.

"Id. at $\S 2000 \mathrm{e}-5(\mathrm{k})$. See generally 54 VA. L. Rev. 491 (1968).

4254 VA. L. Rev. 491 (1968).

${ }^{43}$ Id. at 497-503 (three sources of tort remedies).

4See notes 12 \& 13 supra.

4s See 29 OHIo ST. L.J. 456 (1968). The percentage of successful conciliations has decreased, and the trend continues in that direction-from a success rate of $69 \%$ in 1966 to $57 \%$ in 1967.
} 
may obtain substantial affirmative relief with its greater deterrent effect. Additionally, eliminating the EEOC-filed charge as the sole avenue to "individualized" Title VII relief would have the collateral effect of alleviating some of the harshness imposed by the short statutory periods under the Act. Thus, a federal court enforcing the Act's dictates would employ the applicable statute of limitations of the state in which the action arises-usually two to three years for intentional torts. With such alterations in the availability and effectiveness of relief under Title VlI, the frequency of privately instituted actions can be expected to increase, with a corresponding decrease in discriminatory employment practices. 